\title{
Effects of Iron-Oxide Nanoparticles (Fe304) Released From Synthesized Iron-based Thiourea Catalyst on the Growth, Cell Density, and Pigment Content of Chlorella Vulgaris
}

Tahereh Ebrahini Yazdanabdad

Islamic Azad Universit, Arak Branch

Ali Forghaniha

Islamic Azzad University, Arak Branch

Mozhgan Emtyazjoo ( $\sim$ Moz_emtyazjoo@yahoo.com )

Islamic Azad University Science and Research Branch

Majid Ramezani

Islamic Azad University, Arak Branch

\section{Research Article}

Keywords: Metal pollution, Non-carcinogenic risk, Bioconcentration factor, Microalgae, Bioaccumulation

Posted Date: November 17th, 2021

DOI: https://doi.org/10.21203/rs.3.rs-1013835/v1

License: (c) (i) This work is licensed under a Creative Commons Attribution 4.0 International License.

Read Full License 


\section{Abstract}

This study investigated the effects of $\mathrm{Fe}_{3} \mathrm{O}_{4}$ nanoparticles released from synthesized Thiourea catalyst to Chlorella vulgaris as an essential primary producer in aquatic systems. A range of $\mathrm{Fe}_{3} \mathrm{O}_{4}$ concentrations $\left(0,10,100,250,500,750\right.$, and $\left.1000 \mathrm{mg} \mathrm{L}^{-1}\right)$ was applied for the exposure test. Biological parameters of $C$. vulgaris, including cell density, cell viability, and pigment content were assessed. Bioconcentration factor and bioaccumulation were evaluated for contaminated microalgae. Non-carcinogenic risks were then assessed using target hazard quotient (THQ) for potential human consumptions. Findings showed that C. vulgaris cell numbers increased from 0 to $500 \mathrm{mg} \mathrm{L}^{-1}$ of $\mathrm{Fe}_{3} \mathrm{O}_{4}$. Chlorophyll a represented a timedependent response, and greatest values were detected in 250 and $500 \mathrm{mg} \mathrm{L}^{-1} \mathrm{Fe}_{3} \mathrm{O}_{4}$ at 4.2 and $4 \mathrm{mg} / \mathrm{g}$, respectively. Chlorophyll b content showed a time-related manner in exposure to $\mathrm{Fe}_{3} \mathrm{O}_{4}$ with the highest values recorded at $250 \mathrm{mg} \mathrm{L}^{-1}$ after $96 \mathrm{~h}$. Moreover, bioaccumulation displayed a dose-dependent response as bioaccumulated iron was in the largest amount at $15000 \mu \mathrm{g} / \mathrm{g} \mathrm{dw}$ in $1000 \mathrm{mg} \mathrm{L}^{-1}$, whereas the lowest one was in the control group at $1700 \mu \mathrm{g} / \mathrm{g} \mathrm{dw}$. The bioconcentration factor showed a concentration-relevant decrease in all iron treatments and $10 \mathrm{mg} \mathrm{L}^{-1}$ of $\mathrm{Fe}_{3} \mathrm{O}_{4}$ represented the greatest BCF at 327.3611. Non-carcinogenic risks illustrated negligible hazard $(T H Q<1)$ in a dose-response pattern and the largest EDI and THQ were calculated in $1000 \mathrm{mg} \mathrm{L}^{-1}$ at $7.4332 \mathrm{E}-07\left(\mathrm{mg} \mathrm{kg}^{-1}\right.$ day $\left.^{-1}\right)$ and $1.06189 \mathrm{E}-09$, respectively. In essence, iron is an essential trace element for biological aspects in aquatic systems, but in exceeding concentrations could impose toxicity effects in $C$. vulgaris populations.

\section{Introduction}

Organocatalysts have received a great deal of attention over the last decade due to their low cost, availability, high yield, short reaction time, simplicity of product isolation, clean reaction profile, environmental benignity, recyclability, and reusability [1]. Having a strong hydrogen bonding capability, organic-based catalysts can significantly promote chemical reactions in environmental studies [2]. Urea has been recently applied as an organic base for organocatalysts used in wastewater management and air pollution to remove heavy metals [3]. Thiourea catalyst is generated from magnetic nanoparticles because of their high surface area, low toxicity and superparamagnetic behavior, and potential applications in many fields [4]. Many metals have been used as the metallic base of Thiourea catalyst, including $\mathrm{Al}, \mathrm{Fe}, \mathrm{Cu}, \mathrm{Si}$, and $\mathrm{Zn}$; however, functionalized iron nanoparticles $\left(\mathrm{Fe}_{3} \mathrm{O}_{4}\right)$ are more interesting due to their easily separable, reusable, non-toxic, low cost, and flexible design [5]. In organic chemistry, $\mathrm{Fe}_{3} \mathrm{O}_{4}$ catalyst coated with thiourea is used for the Knoevenagel reaction where formation of $\mathrm{C}-\mathrm{C}$ double bonds and synthesis of $a, \beta$-unsaturated carbonyl compounds from active methylene and carbonyl compounds may occur [7]. Knoevenagel reaction is mainly used in the chemical processes to mitigate the human interference and secure operators from dangerous and carcinogenic solvents [6]. $\mathrm{Fe}_{3} \mathrm{O}_{4}$ nanomaterials play an essential role as a functionalized base for Thiourea catalyst, and is greatly used in such reactions in numerous industrial activities [8]. Such iron-based catalyst can release into the aquatic ecosystems and affect the organisms like microalgae as primary producers in these environments [9]. 
The environmental concentration of iron-based materials has been increased in the biota, including soil, air, and water [10]. Literature have reported the fate, biotransformation, bioaccumulation, and toxicity of such elements in various ecosystems [11, 12]. In particular, aquatic environments are the most important destinations for iron-based compounds through wastewater drainage and landfills in populated areas. $\mathrm{Fe}_{3} \mathrm{O}_{4}$, in general, possess various behaviors when enter to the water systems, and undergo some processes, including aggregation, dissolution, redox reaction, and interaction with potential macromolecules [13]. These iron-based products can act as the best iron resource for microalgae, and in highly-contaminated systems lead to eutrophication and algal bloom [14]. Furthermore, iron-based materials in overloaded-conditions cause bioaccumulation and bioconcentration in the aquatic species, and thus, oxidative stress could result in through reactive oxygen species (ROS) production [15]. Aquatic flora and fauna are more sensitive to toxic materials compared with terrestrial species, and related compounds of iron can easily pass the cell membrane and cause severe damages to enzymes, proteins, and DNA integrity of organisms[16]. Lei et al. (2016) examined the toxicity of iron-based NPs to green algae in terms of fate, particle size, and oxidation effects [17]. Chlorella vulgaris (C. vulgaris) was used as an aquatic biological model to investigate iron-based oxidative stress [18]. The toxicity effects of iron oxide nanoparticles were assessed using Zebrafish (Danio rerio) in early life stages, that mortality, hatching delay, and malformation occurred in exposing to these nanomaterials [19]. The toxicity of nanoparticles to aquatic species has been investigated in numerous studies as Behzadi Tayemeh et al. (2020) examined the toxic effects of silver nanoparticles and ions on $C$. vulgaris biological responses [20]. Sayadi et al. (2020) used blackfish (Capoeta fusca) to study exposure effects of iron oxide nanoparticles and iron salts in causing toxicity, bioaccumulation, and tissue histopathology [21].

Microalga play a vital role in forming the primary production and energy base for all species inhabited in aquatic ecosystems[22, 19]. Such valuable photosynthetic species ranged from microscopic to macro sizes and are the main cause of the food and oxygen production in both freshwater and marine systems. Over the past decade, microalgae have gained significant attention among environmentalists due to their advantageous properties in aquatic ecological balance [23]. Many studies have been conducted concerning the toxic effects of metal contaminants on the biological aspects of microalgae, including growth rate, yield rate, pigment content, reproduction, and nutrient content [24]. Copper nanoparticles caused growth inhibition in Skeletonema costatum in exposing to microplastics [23]. Nutritional characteristics of microalgae examined through exposing to metals and metallic NPs, and pigments, biological macromolecules, and phenolic compounds reduced in the presence of these deleterious materials [26]. For this, microalgae have been always considered as ideal candidates and indicators in biological and ecological monitoring of the aquatic biota [27]. Moreover, phytoplanktons are being consumed as functional foods and reliable supplementary ingredients in human diet [26, 27, 29]. Having the richest source of unsaturated fatty acids, antioxidants, proteins, and pigments, microalgae have played a pivotal role in supplying aquatic-based bioactive compounds for consumers [30].

C. vulgaris is classified as unicellular green microalgae and known as an essential functional food in the world [19]. C. vulgaris is being sold in many countries like Japan, China, Germany, and India as the most 
important algal nutrient in human health and aquaculture activities[31]. This freshwater microalga, in addition, is known for its anticancer, anti-inflammatory, antioxidant, and antibacterial merits, which is widely used in pharmaceutical and food industries [32]. C. vulgaris has a great potential of biosorption in binding with toxic materials and metals dissolved in the water[33,34]. Having intracellular metal binding proteins such as metallothioneins, $C$. vulgaris has been identified as a viable microalga in alleviating the adverse effects of xenobiotics in aquatic ecosystems[35]. In addition, $C$. vulgaris has been an ideal biological model for primary producers to investigate the toxicological effects of metals and nanoparticles released into the aquatic environments. Therefore, this study intended to investigate the effect of iron-based nanoparticles released from synthesized Thiourea catalyst to $C$. vulgaris, as a pivotal primary producer in aquatic systems, in terms of bioaccumulation, bioconcentration, cell growth, pigment content, and risk assessment for potential human consumptions.

\section{Materials And Method}

\subsection{Chemicals and instruments}

All chemicals and reagents were purchased from Merck Company (Germany). Infrared (IR) spectra is applied to analyze the spectral experiment using spectrometer (Shimadzu FT-IR-8400S). Following the chemicals preparation, all first-made products were examined using ${ }^{1} \mathrm{H}$ NMR $(500 \mathrm{MHz})$ spectra and Bruker DRX-500 to identify the chemical characteristics. To solve the chemicals, an advanced spectrophotometer equipped with $\mathrm{CDCl}_{3}$ (as the solvent) and tetramethylsilane (TMS) (as the internal standard) at ambient temperature was applied. Zeiss-Sigma (VP 500) was used to obtain SEM images and EDX spectra was recorded on an Oxford Instrumental ${ }^{\circledR}$ version. A vibrating magnetometer was used to identify the magnetic properties of the synthesized catalyst (MD Co., Iran, www.mdk-magnetic.com). To analyze the thermogravimetric properties, thermal analyzer with a heating rate of $20^{\circ} \mathrm{C} \mathrm{min}^{-1}$ was used over a temperature range of 25 to $1100^{\circ} \mathrm{C}$ under flowing compressed nitrogen.

\subsection{Catalyst preparation}

To synthesize the catalyst, $5 \mathrm{mmol} \mathrm{FeCl} 3.6 \mathrm{H}_{2} \mathrm{O}$ and $2.5 \mathrm{mmol} \mathrm{FeCl} \cdot .4 \mathrm{H}_{2} \mathrm{O}$ were dissolved in $100 \mathrm{~mL}$ deionized water under vigorous stirring (800 rpm). Then, $\mathrm{NH}_{4} \mathrm{OH}$ solution $(25 \%, \mathrm{w} / \mathrm{w}, 30 \mathrm{~mL})$ was added to the prepared mixture at room temperature until adjusting the $\mathrm{pH}$ above 11. To form a black suspension, $\mathrm{NH}_{4} \mathrm{OH}$ solution was continuously added to maintain the $\mathrm{pH}$ value between 11 and 12 . The resulting black dispersion was continuously stirred for $1 \mathrm{~h}$ at room temperature and then refluxed for $6 \mathrm{~h}$. Following the methodology, ethanol $(40 \mathrm{~mL})$ was applied at $40^{\circ} \mathrm{C}$ for $1 \mathrm{~h}$ to purify $\mathrm{Fe}_{3} \mathrm{O}_{4}$ nanoparticles for coating a layer of silica on the surface of the catalyst. Subsequently, tetraethylorthosilicate (TEOS, $10 \mathrm{~mL}$ ) was charged to the reaction vessel, and the mixture was continuously stirred for $24 \mathrm{~h}$. The silica-coated nanoparticles were collected by a magnet, followed by washing five times with $\mathrm{EtOH}$, diethylether and drying at $100^{\circ} \mathrm{C}$ in vacuum for $12 \mathrm{~h}$. A sample of $\mathrm{MNPs}^{-S_{i} \mathrm{O}_{2}}(1 \mathrm{~g})$ dispersed in a mixture of $50 \mathrm{~mL}$ of dry toluene containing (3-chloropropyl) trimethoxy-silane $(1 \mathrm{ml})$ as the effective linker with two different electrophile heads. The mixture was refluxed for $48 \mathrm{~h}$. The final product was separated by filtration, 
washed with toluene, and dried under vacuum for $24 \mathrm{~h}$ at $150^{\circ} \mathrm{C}$. The prepared MNPs@SiO ${ }_{2} @-\mathrm{Si}-\left(\mathrm{CH}_{2}\right)_{3}-\mathrm{Cl}$ $(1 \mathrm{~g})$ and $\mathrm{KI}(1.66 \mathrm{~g}, 0.01 \mathrm{~mol})$ were added to a solution of thiourea $(0.76 \mathrm{~g}, 0.01 \mathrm{~mol})$ and $\mathrm{K}_{2} \mathrm{CO}_{3}(1.38 \mathrm{~g})$ dissolved in acetonitrile $(50 \mathrm{~mL})$ transferred to a round-bottom flask and the mixture was stirred under reflux condition for $8 \mathrm{~h}$. The obtained solid was then magnetically collected from the solution and washed abundantly with water/ethanol followed by drying at $80^{\circ} \mathrm{C}$ for $12 \mathrm{~h}$.

\subsection{Characterization of synthesized Thiourea catalyst}

To identify the characteristics of Synthesized catalyst, a range of optico-chemical techniques, including FT-IR, VSM, XRD, SEM, EDX, and TGA were applied. Results relating to the FT-IR spectra of magnetic NPs $\left(\mathrm{Fe}_{3} \mathrm{O}_{4} @ \mathrm{SiO}_{2}\right)$ and $\mathrm{Fe}_{3} \mathrm{O}_{4} @ \mathrm{SiO}_{2} @ \mathrm{SiO}_{3}-\left(\mathrm{CH}_{2}\right)_{3}$-thiourea are demonstrated in figure 1 (IV). The peaks at 568 and $801 \mathrm{~cm}^{-1}$ are assigned to the $\mathrm{Fe}^{+3}-\mathrm{O}^{-}$and $\mathrm{Fe}^{+2}-\mathrm{O}^{-}$symmetrical stretching vibrations, respectively. The covalent bond between silicon and magnetite surface is underlined by the appearance of the band at $1092 \mathrm{~cm}^{-1}$ for Si-0 groups. Moreover, absorption bands at $800-950 \mathrm{~cm}^{-1}$ are associated with vibrating bands for $\mathrm{Si}-\mathrm{O}-\mathrm{Si}$ groups (Fig. 1-IV). These results indicated that the $\mathrm{SiO}_{2}$ layer was formed on the surfaces of $\mathrm{Fe}_{3} \mathrm{O}_{4}$. Signals appeared at $3421 \mathrm{~cm}^{-1}$ regions can be assigned to the $\mathrm{N}-\mathrm{H}$ bending, and $1634 \mathrm{~cm}^{-1}$ are attributed to $(\mathrm{C}=\mathrm{S})$ stretching of thiourea. Magnetic hysteresis measurements were done in an applied magnetic field at r.t, with the field sweeping from -10000 to +10000 Os using a vibrating sample magnetometer (VSM) as a scientific instrument for measuring magnetic properties (Fig. 1-II). The magnetic saturation value of thiourea functionalized MNPs@SiO ${ }_{2} @ S_{3}{ }_{3}\left(\mathrm{CH}_{2}\right)_{3} \mathrm{NHCSNH}_{2}$ is $23 \mathrm{emu} / \mathrm{g}$. In addition, the XRD patterns of $\mathrm{Fe}_{3} \mathrm{O}_{4} @ \mathrm{SiO}_{2} @ \mathrm{SiO}_{3}\left(\mathrm{CH}_{2}\right)_{3} \mathrm{NH}(\mathrm{CS}) \mathrm{NH}_{2}$ are demonstrated in figure 1-III. XRD contains seven characteristic peaks $\left(2 \theta=21.25^{\circ}, 37.29^{\circ}, 43.73^{\circ}, 52.56^{\circ}, 65.09^{\circ}, 69.73^{\circ}, 76.81^{\circ}\right)$ which match with the peaks of $\mathrm{Fe}_{3} \mathrm{O}_{4}$ and this confirms that the crystalline structure of $\mathrm{Fe}_{3} \mathrm{O}_{4}$ does not change during functionalization of MNPs (Fig. 1-III).

The morphology of $\mathrm{Fe}_{3} \mathrm{O}_{4} @ \mathrm{SiO}_{2} @ \mathrm{SiO}_{3}\left(\mathrm{CH}_{2}\right)_{3} \mathrm{NH}(\mathrm{CS}) \mathrm{NH}_{2}$ before (Fig. 1-VII A), and after (Fig. 1-VII B) reaction was visualized using scanning electron microscopy (SEM) images as depicted in figure 1-VII. Based on the SEM analysis, the catalyst was made up of nanometer-sized iron particles shaping spherical morphology. Energy-dispersive X-ray spectroscopy (EDX) method was used to characterize the elemental composition of $\mathrm{Fe}_{3} \mathrm{O}_{4} @ \mathrm{SiO}_{2} @ \mathrm{SiO}_{3}\left(\mathrm{CH}_{2}\right)_{3} \mathrm{NHCSNH}_{2}$ (Fig. 1-VI). According to the EDX analysis, the well-dispersion of $\mathrm{Fe}_{3} \mathrm{O}_{4}$ nanoparticles was obtained through the preparation process. Thermal Gravimetric Analysis (TGA) and Differential Thermal Analysis (DTA) were applied in three steps (Fig. 1-V). The first rupture is associated with the loss of water $1 \% \mathrm{wt}$ around $60^{\circ} \mathrm{C}$, and the second and main loss in weight was recorded at $5 \% \mathrm{wt}, 0.083 \mathrm{~mol} / 100 \mathrm{~g}$ catalyst, associated with the elimination of thiourea and its propyl spacer between 200 to $300^{\circ} \mathrm{C}$. The final thermal destruction, approximately $1 \% \mathrm{wt}$, was observed from 350 to $700^{\circ} \mathrm{C}$, corresponding loss of silica portion of nanoparticles.

The doublet peak was observed in the low field relating to the $H^{1}$, near electron donor group. In addition, the unit singlet peak was related to the $\mathrm{H}^{3}$ and another doublet peak was for $\mathrm{H}^{2}$ that it depended on the 
group connecting to the aromatic bond which is the same for electron donor group, but the peak $\mathrm{H}^{2}$ had shifted to $\mathrm{NO}_{2}$ as this group had responded and shifted to the high/low field.

\subsection{Algal cultivation}

C. vulgaris was cultivated using the sterilized Bold's Basal Medium (BBM) as prescribed by Behzadi Tayemeh et al. (2020b). The cultivation was performed for $96 \mathrm{~h}$, and an initial density of $10^{7}$ cells $\mathrm{mL}^{-1}$ in $1.5 \mathrm{~L}$-glass vessels was used as a stock solution.

\subsection{Toxicity tests and exposure experiments}

Exposure tests were conducted in the media using a range of concentrations, including $0,10,100,250$, 500,750 , and $1000 \mathrm{mg} \mathrm{L}^{-1} \mathrm{Fe}_{3} \mathrm{O}_{4} \mathrm{NPs}$. Exposure concentrations were selected according to the coated magnetic $\mathrm{Fe}_{3} \mathrm{O}_{4} \mathrm{NPs}$ on a synthesized Theurea catalyst. For each treatment, three replicates were considered, and exposure tests were carried out using OECD 201 (OECD, 2011) protocols and guidelines. During the incubation period, cool white fluorescent lights (40W FL T10 230 V G13; 12 h light: 12 h dark regime) were used with constant intensity of $1000 \mu \mathrm{mol}$. photons. $\mathrm{m}^{-2} \cdot \mathrm{s}^{-1}$ on the glass vessels aerated from the bottom and the temperature was adjusted at $26 \pm 1^{\circ} \mathrm{C}$.

\subsection{Algal growth}

During the exposure time, the density of algal cells was daily evaluated at 24, 48, 72, and $96 \mathrm{~h}$ after exposure test. For this, two procedures, including optical density (OD) and visible light microscopy were used to calculate the cell numbers. Spectrophotometric method (PerkinElmer Lambda 25 UV-VIS Spectrometer) at the absorbance of $680 \mathrm{~nm}$ was used for OD method, and light microscope equipped with a Neubauer chamber was applied to perform the visual count in triplicates for each treatment (OECD, 2011).

\subsection{Pigment analysis}

Pigments, including Chlorophyll a, Chlorophyll b, and carotenoid were considered as microalgae pigments and evaluated using a standard protocol prescribed by Silkina et al. (2015) with some modifications [36]. Following the pigment analysis, a volume of $13 \mathrm{ml}$ medium was centrifuged for obtaining cultivated algal cells using $20,000 \mathrm{rpm}$ for $5 \mathrm{~min}$ at $4^{\circ} \mathrm{C}$. The supernatant was rejected and then the maintained cells were preserved at $-80^{\circ} \mathrm{C}$ until experiments. Pigments were extracted according to the method stated by Tsiola et al. (2017) who used $1.5 \mathrm{ml}$ of $90 \%$ ethanol added to the collected cells and then vortexed severely for 2 min and kept for $24 \mathrm{~h}$ in a dark condition at room temperature [37]. A microplate reader (BioTek, $800 \mathrm{TS}$ Absorbance Reader; USA) was used to read the pigments in each treatment using $150 \mu$ in triplicates at 470,666 , and $653 \mathrm{~nm}$.

\subsection{Bioaccumulation and bioconcentration factor}

To measure intracellular $\mathrm{Fe}_{3} \mathrm{O}_{4}$ concentrations, algal cells were first collected from the water medium and then were thoroughly washed with cultured medium (without heavy metal ion) to remove the potential 
extracellular $\mathrm{Fe}_{3} \mathrm{O}_{4}$ ions. Digestion was conducted using $\mathrm{HNO}: \mathrm{HClO}_{4}$ at $80^{\circ} \mathrm{C}$ and $130^{\circ} \mathrm{C}$ for 1 and $3 \mathrm{~h}$, respectively, based on the method prescribed by Qian et al. (2011) with some modifications [28]. Digested material was diluted with de-ionized water, and $\mathrm{Fe}_{3} \mathrm{O}_{4}$ concentrations were detected using flame atomic absorption spectrophotometer (Model 670G, USA). Bioconcentration factor (BCF) was calculated using equation 1 as suggested by Kuppu et al. ( 2018).

$$
\operatorname{BCF}\left(\operatorname{Lkg}^{-1}\right)=\frac{\mathrm{CMDT}}{\mathrm{CSMW}}
$$

1

Where CMDT is concentration of metal in dry tissue $\left(\mathrm{mg} \mathrm{kg}^{-1}\right)$, and CSMW is the concentration of same metal in water $\left(\mathrm{mg} \mathrm{L}^{-1}\right)$.

\subsection{Health risk assessment of contaminated $\mathrm{C}$. vulgaris}

The estimated daily intake (EDI) and target hazard quotient (THQ) were used to evaluate the noncarcinogenic risk of $\mathrm{Fe}_{3} \mathrm{O}_{4}$ accumulated in $\mathrm{C}$. vulgaris. Based on the method prescribed by Alipour and Banagar (2018) EDI and THQ were calculated using equations 2 and 3, respectively.

$$
\operatorname{EDI}\left(\mathrm{mgkg}^{-1} \mathrm{day}^{-1}\right)=\frac{\mathrm{EF} \times \mathrm{ED} \times \mathrm{AIR} \times \mathrm{C}}{\mathrm{BW} \times \mathrm{ATn}}
$$

2

$$
\mathrm{THQ}=\frac{\mathrm{EF} \times \mathrm{ED} \times \mathrm{AIR} \times \mathrm{C}}{\mathrm{RfD} \times \mathrm{BW} \times \mathrm{ATn}} \times 10^{-3}
$$

where $E F$ is the exposure frequency ( 365 days year $^{-1}$ ); $E D$ is the exposure duration (70 years, average lifetime for adults); AIR is the algal ingestion rate $\left(0.0035 \mathrm{Kg} \mathrm{person}^{-1}\right.$ day $\left.^{-1}\right) ; \mathrm{C}$ is the $\mathrm{Fe} 304$ ions in algae $\left(\mathrm{mg} \mathrm{g}^{-1}\right)$; $\mathrm{RfD}$ is the oral reference dose $\left(\mathrm{Fe}=0.7 \mathrm{mg} \mathrm{kg}^{-1} \mathrm{day}^{-1}\right)$; $\mathrm{Bw}$ is the average adult body weight $(70 \mathrm{~kg})$; and ATn is the average exposure time for non-carcinogenic risk (365 days/year $\mathrm{x}$ number of exposure years, assuming 70 years). Non-carcinogenic risk grouping was performed using the method prescribed by Cheng et al. (2018). For target hazard quotient, THQ $\geq 1$ showed the presence of noncarcinogenic risk, and THQ $<1$ represented negligible hazard for people.

\subsection{Statistical analysis}

All of the analyses and comparisons were conducted using SPSS software version 19.0 (SPSS, Chicago IL, USA). Kolmogorov-Smirnov test was performed to assess the normality of data, and one-way ANOVA was used to determine possible differences between treatments. In all analyses, data were presented as mean \pm SD, and differences were considered significant at $P<0.05$. For data management and drawing 
graphs, Microsoft Excel (version 2016, windows 7) was applied to define and calculate the risk assessment analysis.

\section{Results}

\subsection{Cell density and algal growth}

Cell density analysis is represented in figure 2. Based on the findingS, cell density of $C$. vulgaris showed that the number of cells increased with the elevation of iron-based NPs from 0 to $100 \mathrm{mg} \mathrm{L}^{-1}$ while in higher concentrations (i.e. 250, 500, 750, and 1000) demonstrated a decrease, especially after 72 and 96 $\mathrm{h}$ exposure period. Results showed that cell density elevated with the increase of nanomaterial concentration from 0 to $500 \mathrm{mg} \mathrm{L}^{-1}$ after 0,24 , and $48 \mathrm{~h}$ exposure time (Fig. 2).

\subsection{Pigment analysis}

Results relating to the chlorophyll a content is depicted in figure 3. It is apparent that the content of chlorophyll a was in the lowest level after $24 \mathrm{~h}$ exposure time, whereas in a 96-h period the highest chlorophyll a was recorded in all treatments. Indeed, chlorophyll a content showed a time-dependent response to the concentration of iron nanoparticles. Moreover, in treatments exposed to 250 and $500 \mathrm{mg}$ $\mathrm{L}^{-1}$, chlorophyll a had 4.2 and $4 \mathrm{mg} / \mathrm{g}$, respectively (Fig. 3). Chlorophyll b, in addition, demonstrated a time-relevant response to $\mathrm{Fe}_{3} \mathrm{O}_{4} \mathrm{NPs}$ as chlorophyll a content increased from 0 to $96 \mathrm{~h}$ after exposure period in all concentrations (Fig. 4). The greatest pigment content was detected at the end of the experiment $\left(96 \mathrm{~h}\right.$ ) while the lowest one was observed in the first day of the test. In terms of $\mathrm{Fe}_{3} \mathrm{O}_{4} \mathrm{NPs}$ exposure doses, algal populations exposed to 250 and $1000 \mathrm{mg} \mathrm{L}^{-1}$ illuminated the highest and lowest chlorophyll b content, respectively. Findings demonstrated that carotenoid underwent a concentrationdependent decrease in all tested groups (i.e. $0,10,100,250,500,750$, and $1000 \mathrm{mg} \mathrm{L}^{-1}$ ). Furthermore, a time-relevant manner was observed between $\mathrm{Fe}_{3} \mathrm{O}_{4}$ NPs concentrations, and carotenoid content increased with the elevation of exposure time from 24 to $96 \mathrm{~h}$ in control, 10 , and $100 \mathrm{mg} \mathrm{L}^{-1}$ iron nanomaterials. However, $C$. vulgaris populations exposed to $250,500,750$, and $1000 \mathrm{mg} \mathrm{L}^{1}$ showed the lowest carotenoid content in comparison with the lower concentrations and control group (Fig. 5).

\subsection{Bioaccumulation and bioconcentration factor}

Bioaccumulated $\mathrm{Fe}_{3} \mathrm{O}_{4}$ in $C$. vulgaris populations exposed to different concentrations is represented in figure 6. Based on the outcomes, bioaccumulation factor exhibited a concentration-related pattern in the tested groups. The highest bioaccumulation recorded at $15072.9 \mu \mathrm{g} / \mathrm{g} \mathrm{dw}$ in exposing to $1000 \mathrm{mg} \mathrm{L}^{-1}$ and the lowest one identified at $1592.32 \mu \mathrm{g} / \mathrm{g} \mathrm{dw}$ in the control group where algal populations did not expose to $\mathrm{Fe}_{3} \mathrm{O}_{4}$ concentration (Fig. 5) and Table 1). Findings regarding the bioconcentration factor (BCF) illustrated that $10 \mathrm{mg} \mathrm{L}^{-1}$ of $\mathrm{Fe}_{3} \mathrm{O}_{4}$ had the greatest $\mathrm{BCF}$ at 327.3611 , whereas other concentrations $(0$, 100, 250, 500, 750, and 1000) demonstrated BCF no more than 50 (Fig. 7). 
Table 1

Detected concentrations of $\mathrm{Fe}_{3} \mathrm{O}_{4}$ in contaminated $C$. Vulgaris

\begin{tabular}{|ll|}
\hline $\mathrm{Fe}_{3} \mathrm{O}_{4}$ concentration $\left(\mathrm{mg} \mathrm{L}^{-1}\right)$ & $\begin{array}{l}\text { Bioaccumulation }(\mu \mathrm{g} / \mathrm{g} \mathrm{dw}) \\
\text { Mean } \pm \mathrm{SD}\end{array}$ \\
\hline Control & $1592.32 \pm 312.714$ \\
\hline 10 & $3273.61 \pm 244.298$ \\
\hline 100 & $4086.32 \pm 1343.91$ \\
\hline 250 & $4965.49 \pm 1668.21$ \\
\hline 500 & $8696.36 \pm 514.39$ \\
\hline 750 & $11203.9 \pm 2152.33$ \\
\hline 1000 & $15072.9 \pm 1928.64$ \\
\hline
\end{tabular}

\subsection{Health risk assessment}

Risk assessment analysis presented in Table 2. Outcomes suggested that estimated daily intake (EDI) increased with the elevation of $\mathrm{Fe}_{3} \mathrm{O}_{4}$ concentration, and the highest EDI was calculated at 7.4332E-07 for C. vulgaris populations who were exposed to $1000 \mathrm{mg} \mathrm{L}^{-1}$. Target hazard quotient (THQ) revealed a concentration-dependent response to iron concentrations, and the largest THQ was obtained in exposing to $1000 \mathrm{mg} \mathrm{L}^{-1}$ at $1.06189 \mathrm{E}-09$. THQ in all contaminated populations of $C$. vulgaris to $\mathrm{Fe}_{3} \mathrm{O}_{4}$ was below 1 (i.e. $T H Q<1$ ), and therefore, cultivated microalgae represented negligible hazard for algal consumers.

Table 2

Estimated daily intake (EDI) and target hazard quotient (THQ) of contaminated C. vulgaris.

\begin{tabular}{|lll|}
\hline $\mathbf{m g ~ k g}^{-1}$ day $^{-1}$ & EDI & THQ \\
\hline 0 & $7.85253 \mathrm{E}-08$ & $1.12179 \mathrm{E}-10$ \\
\hline 10 & $1.61438 \mathrm{E}-07$ & $2.30626 \mathrm{E}-10$ \\
100 & $2.01517 \mathrm{E}-07$ & $2.87882 \mathrm{E}-10$ \\
\hline 200 & $2.44873 \mathrm{E}-07$ & $3.49819 \mathrm{E}-10$ \\
\hline 500 & $4.28861 \mathrm{E}-07$ & $6.12659 \mathrm{E}-10$ \\
\hline 750 & $5.5252 \mathrm{E}-07$ & $7.89314 \mathrm{E}-10$ \\
\hline 1000 & $7.4332 \mathrm{E}-07$ & $1.06189 \mathrm{E}-09$ \\
\hline
\end{tabular}

\section{Discussion}


Iron is one of the most abundant metal in the earth's crust (34.6\%) and would be naturally available in the environment [42]. This vital trace element plays a crucial role in producing materials in the photosynthetic organisms as well as cell division processes. There are a variety of iron-based compounds in the environment, but the most common forms are $\mathrm{Fe}_{2} \mathrm{O}_{3}, \mathrm{Fe}_{3} \mathrm{O}_{4}, \mathrm{FeSO}_{4}, \mathrm{FeCl}_{3}$, and $\mathrm{Fe}_{2} \mathrm{NO}_{3}$. Iron in certain concentrations is essential for living-beings in the environment, but at higher concentrations, it can be toxic. In microalgae population, iron involves in metabolism pathways, including photosynthesize, pigment, DNA synthesis, nitrogen fixation, and respiration. Furthermore, iron-based materials are constructed through a wide range of human-made activities which result in iron pollution in the biota. Synthesized catalysts are designed to functionalize chemical reactions via reducing the cost and increasing the speed of processes. For this, many industries have applied organocatalysts containing metals as a reliable and viable base. The ever-increasing application of such catalysts has resulted in environmental pollution and aquatic toxicity for many organisms. Literature reported that wastewater from industrial developments contains 10 to $120 \mathrm{mg} \mathrm{L}^{-1}$ iron [43]. Iron content of wastewater and sediment were estimated to be 50 to $3500 \mu \mathrm{g} \mathrm{L}^{-1}$ and 4300 to $7000 \mathrm{mg} \mathrm{kg}^{-1}$ in a lake located in Western Australia. Copper smelter companies are one of the most important sources of iron-based materials that cause $882 \mathrm{mg} \mathrm{kg}^{-1}$ iron in the sediment. Our findings revealed that the bioaccumulation of $\mathrm{Fe}_{3} \mathrm{O}_{4} \mathrm{NPs}$ in C. vulgaris has a concentration-dependent manner in response to iron-based catalyst used in this study. Fe304 accumulated increasingly from $3273.61 \pm 244.298 \mu \mathrm{g} / \mathrm{g} \mathrm{dw}$ in populations exposed to $10 \mathrm{mg} \mathrm{L}^{-1}$ to $15072.9 \pm 1928.64 \mu \mathrm{g} / \mathrm{g}$ dw detected in $1000 \mathrm{mg} \mathrm{L}^{-1}$ concentration. To support this, $C$. vulgaris has a great potential of absorption and bioaccumulation of environmental metals and is known as an accumulator used in toxicological studies. This bioindicator possesses a hard and thick cell wall containing a considerable amount of fiber that results in absorbing metal ions released into the aquatic biota. Metals such as iron are more desire to absorb and accumulate in the body of aquatic species, rather than being dissolved in the water. Trace elements could be adsorbed by the fish body and its organs in aquatic systems [44]. Another study was conducted using four species of marine algae to evaluate their bioaccumulated iron and its risk for human consumption. Results showed that Gracilariopsis sp. and Sargassum sp. contained larger amount of iron at 1960 and $1570 \mu \mathrm{g} / \mathrm{g} \mathrm{dw}$, respectively, compared to other species. BCF demonstrated that there is a concentration-relevant decrease among populations exposed to $\mathrm{Fe}_{3} \mathrm{O}_{4}$, and the highest value was calculated for $10 \mathrm{mg} \mathrm{L}^{-1}$ treatment at 327.3611 , whereas algae exposed to $1000 \mathrm{mg} \mathrm{L}^{-1}$ showed the lowest BCF at 15.07287 after $96 \mathrm{~h}$ of exposure. BCF has indirect relationship with the metal concentration exposed to the water medium, but with the increase of bioaccumulated $\mathrm{Fe}_{3} \mathrm{O}_{4}$ in algal body, this factor elevates. In general, microalgae are classified as good metal accumulators in aquatic systems, and BCF > 1000 suggested that the studied species has a great ability to bioconcentrate metals. Researchers claimed that marine diatom Phaeodactylum tricornutum could actively adsorb Cd (II) ions to remove such toxic materials from the water. They stated P. tricornutum showed BCF is a stronger cadmium bioconcentrator as its BCF was above 1000 in most tested concentrations [45]. In the present study, there was no BCF higher than 327.3611 (10 $\left.\mathrm{mg} \mathrm{L}^{-1}\right)$ and most tested concentrations displayed BCF below 50. To support this, a complete biosorption can occur by microalgae cells in case they expose to lower $\mathrm{Fe}_{3} \mathrm{O}_{4}$ concentrations, 
and in turn, higher $\mathrm{BCF}$ could be obtained. With the increase of $\mathrm{Fe}_{3} \mathrm{O}_{4}$ concentration in the water, binding sites in the cell wall of the $C$. vulgaris are rapidly saturated, which inhibit the binding of more metal ions [45]. Moreover, in highly metal-contaminated environments, intracellular mechanisms in $C$. vulgaris regulate the gradient concentration between the water and organism [46].

According to outcomes emerged to this study, cell density of $C$. vulgaris populations increased in lower concentrations of $\mathrm{Fe}_{3} \mathrm{O}_{4}$ at 10,100 , and $250 \mathrm{mg} \mathrm{L}^{-1}$ after 72 and $96 \mathrm{~h}$ exposure period, and the highest cell growth was observed in populations exposed to $100 \mathrm{mg} \mathrm{L}^{-1}$ iron. However, in higher concentrations (i.e. $250,500,750$, and $1000 \mathrm{mg} \mathrm{L}^{-1}$ ) cell density was inhibited. It is investigated that the cell density in $C$. vulgaris populations exposed to silver nanoparticles (AgNPs) and silver ions $\left(\mathrm{AgNO}_{3}\right)$ during a $72-\mathrm{h}$ exposure time increased firstly with the elevation of metal nanoparticles and ions, but in higher exposure concentrations and times, it remained stable due to inhibitory effects of such materials [20]. Aquatic microalgae possess limitations to use micronutrients and absorb trace elements in their inhabitants, and in higher concentrations these essential elements act as growth inhibitors. These findings mirrored those reported by Naorbe and Serrano (2018) who stated that microalgae Tetraselmis tetrathele showed inhibitory effects in exposing to $\mathrm{Hg}$ and $\mathrm{Cd}$ ions. They added that $\mathrm{Hg}$ and $\mathrm{Cd}$ in lower concentrations (i.e. $0,0.1,0.3,0.5,1$, and $2 \mathrm{mg} \mathrm{L}^{-1}$ ) showed no change in the cell density, while in higher doses at 3,4 , and 5 $\mathrm{mg} \mathrm{L}^{-1}$ after $72 \mathrm{~h}$ of exposure time inhibitory effects were observed [48]. Furthermore, our results demonstrated that in the control group as well as after 24 and $48 \mathrm{~h}$ of exposure experiment cell density increased even at higher $\mathrm{Fe}_{3} \mathrm{O}_{4}$ concentrations (i.e. $500 \mathrm{mg} \mathrm{L}^{-1}$ ); however, cell growth remained stable in facing 750 and $1000 \mathrm{mg} \mathrm{L}^{-1}$. This may mean that microalgae such as $C$. vulgaris has their own growth regulatory mechanisms that act as inhibitory factors to adjust their populations based on the environmental conditions. The suppression of $C$. vulgaris growth in exposing to cadmium, lead, and copper stress was studied, and results concerned that the growth and chemical compositions decreased during the first $48 \mathrm{~h}$ of exposure time, and copper was more effective inhibitory factor than lead and cadmium to prevent cell growth [49]. Increasing on iron bioavailability above $200 \mu \mathrm{M}$ could mitigate the growth rate of $C$. vulgaris populations exposed to Fe and increased the amount of lipid radical content in the intracellular space [18].

Pigment analysis, in this study, showed that chlorophyll a content increased over the exposure period (i.e. $0,24,48,72$, and $96 \mathrm{~h}$ ) in all tested concentrations and the highest amount of this pigment was recorded after $96 \mathrm{~h}$ of exposure test. Obtained results indicated that $C$. vulgaris could produce chlorophyll a in a concentration-relevant increase up to $250 \mathrm{mg} \mathrm{L}^{-1}$, but in further $\mathrm{Fe}_{3} \mathrm{O}_{4}$ concentrations it decreased to $1000 \mathrm{mg} \mathrm{L}^{-1}$. Metal toxicity can cause a serious reduction in the production of chlorophyll a due to its adverse effects on protein construction. $C$. vulgaris pigment content decreased in exposing to supermagnetic iron oxide nanoparticles $\left(\mathrm{Fe}_{3} \mathrm{O}_{4}\right)$ in a range of concentrations from 12.5 to $400 \mathrm{\mu g} \mathrm{ml}^{-1}$ [39]. Pigment content of microalgae can be used as a reliable biomarker in investigating the health status of the organism, and in whole, community and ecosystem. Literature reported that the most important reason regarding the pigment reduction in microalgae is due to adaptation to unsuitable environmental 
conditions through changing the pigments to supply organic nitrogen [51]. According to our results, chlorophyll b content showed a similar pattern as chlorophyll a, and a significant increase was observed during 96-h exposure time. The highest and lowest chlorophyll b were identified at 250 and $1000 \mathrm{mg} \mathrm{L}^{-1}$, respectively. Carotenoid content of the studied microalgae showed a concentration-related decrease from 0 to $1000 \mathrm{mg} \mathrm{L}^{-1}$. Literatures have proven that the loss of pigment content during the exposure period to metals is mainly because of damage in chloroplast ribosome as well as inhibition in the electron transport chain in the donor center of the $C$. vulgaris cells [52]. In toxic concentration, $\mathrm{Fe}_{3} \mathrm{O}_{4}$ interfere in the pigment production process and alter the essential enzymes and proteins accounted for pigment synthesis [41]. It is highly possible that with the ever-increasing applications of iron-based catalysts in chemical reactions used for various industries, the environmental concentration of $\mathrm{Fe}_{3} \mathrm{O}_{4}$ increase in the aquatic biota, including freshwater rivers, marine environments, lakes, and wetlands.

The importance of microalgae as functional foods and supplementary ingredients in human diet has been proven in many studies [54-57]. Having a diverse range of unsaturated fatty acids, antioxidants, omega-3, proteins, and pigments, $C$. vulgaris has engrossed many attentions among nutrition scientists and aquaculture companies. However, the health status of the $C$. vulgaris, in terms of bioaccumulated metals, is vital for those who consider such valuable ingredients in their daily diets. Because of this, carcinogenic and non-carcinogenic risk assessment tests are applied to examine the potential risk of edible microalgae for consumers. In this study, estimated daily intake (EDI) and target hazard quotient (THQ) were used to calculate non-carcinogen risk of contaminated $C$. vulgaris. In all contaminated $C$. vulgaris exposure tests, THQ was below 1 (the highest value: 1.06189E-09) and calculated as $\mathrm{THQ}<1$ meaning that iron-based catalysts had no non-carcinogenic risk for people in exposing to used $\mathrm{Fe}_{3} \mathrm{O}_{4}$ concentrations in this study.

\section{Conclusion}

This study investigated the toxicity of $\mathrm{Fe}_{3} \mathrm{O}_{4}$ concentrations used in Thiourea synthesized catalyst to $C$. vulgaris as an essential primary producer in aquatic ecosystems. In response to $\mathrm{Fe}_{3} \mathrm{O}_{4}$ concentrations, cell density, pigment analysis, bioaccumulation, and bioconcentartion factor were assessed in $C$. vulgaris populations. Non-carcinogenic risk of contaminated microalgae, moreover, was calculated using EDI and THQ indices. According to the findings, $\mathrm{Fe}_{3} \mathrm{O}_{4}$ in lower concentrations (i.e. 10, 100, and $250 \mathrm{mg} \mathrm{L}^{-1}$ ) was pleasant for the cell growth, whereas in higher doses (i.e. 500, 750, and $1000 \mathrm{mg} \mathrm{L}^{-1}$ ) showed inhibitory effects for cell density, especially after 72 and $96 \mathrm{~h}$. Chlorophyll a and b content increased in 10, 100, and 250 concentrations, while carotenoids represented a dose-relevant decrease to $\mathrm{Fe}_{3} \mathrm{O}_{4}$ concentrations. Although iron is a vital micronutrient for algal viability and reproduction, inhibitory and toxicity effects may occur in its exceeding concentrations above $500 \mathrm{mg} \mathrm{L}^{-1}$. As a strong accumulator in aquatic systems, $C$. vulgaris, could desire to absorb released $\mathrm{Fe}_{3} \mathrm{O}_{4}$ ions, that led to increasing bioaccumulation with the elevation of iron concentrations. $C$. vulgaris possesses a great capacity to bioconcentrate iron nanoparticles, and in this regard, this species plays an essential role in biomagnification through food 
web in aquatic environments. EDI and THQ revealed that non-carcinogenic risk of $\mathrm{Fe}_{3} \mathrm{O}_{4}$ was at negligible risk $(T H Q<1)$ for people. Taken together, although iron-based organocatalysts used in industrial applications are green and safe, in over-used conditions act as inhibitor for primary producers like $C$. vulgaris and threaten the health status of consumers as aquatic functional food.

\section{Declarations}

\section{Declaration of interests}

The authors declare that they have no known competing financial interests or personal relationships that could have appeared to influence the work reported in this paper.

\section{Author contributions}

Taherh Ebrahini Yazdanabdad: Conception and design, investigation and research, drafting of the article, Ali Forghaniha: critical revision of the article for important intellectual content, methodology and supervision, Mozhgan Emtyazjoo: final approval of the article, collection and assembly of data, Majid Ramezani: language revisions and finalizing the manuscript.

\section{Acknowledgements}

The authors declare that they have received no fund or grant as financial support for this study. They also would like to express their gratitude and appreciation for Dr. Ali Forghaniha and Dr. Mozhgan Emtiazjoo, whose guidance, support and encouragement has been invaluable throughout this study.

\section{References}

1. Dekamin MG, Alikhani M, Javanshir S (2016) Organocatalytic clean synthesis of densely functionalized $4 \mathrm{H}$-pyrans by bifunctional tetraethylammonium 2-(carbamoyl)benzoate using ball milling technique under mild conditions. Green Chem Lett Rev 9:96-105. https://doi.org/10.1080/17518253.2016.1139191

2. Karlsson S, Högberg HE (2003) Organocatalysts promote enantioselective 1,3-dipolar cycloadditions of nitrones with 1-cycloalkene-1-carboxaldehydes. European J Org Chem 2782-2791. https://doi.org/10.1002/ejoc.200300172

3. Roy Chowdhury A, Maiti S, Mondal A, Das AK (2020) Picolinohydrazide-Based Covalent Organic Polymer for Metal-Free Catalysis and Removal of Heavy Metals from Wastewater. J Phys Chem C 124:7835-7843. https://doi.org/10.1021/acs.jpcc.0c00664

4. Arefi M, Kazemi Miraki M, Mostafalu R et al (2019) Citric acid stabilized on the surface of magnetic nanoparticles as an efficient and recyclable catalyst for transamidation of carboxamides, phthalimide, urea and thiourea with amines under neat conditions. J Iran Chem Soc 16:393-400. https://doi.org/10.1007/s13738-018-1523-8 
5. Roto R, Yusran Y, Kuncaka A (2016) Magnetic adsorbent of Fe 304 @SiO 2 core-shell nanoparticles modified with thiol group for chloroauric ion adsorption. Appl Surf Sci 377:30-36. https://doi.org/10.1016/j.apsusc.2016.03.099

6. Khare R, Pandey J, Smriti S, Ruchi R (2019) The Importance and Applications of Knoevenagel Reaction (Brief Review). Orient J Chem 35:423-429. https://doi.org/10.13005/ojc/350154

7. Fallah-Mehrjardi M (2017) Fe304@Silica Sulfuric Acid: An Efficient and Heterogeneous Nanomagnetic Catalyst in Organic Reactions. Mini Rev Org Chem 14:122-129. https://doi.org/10.2174/1570193×14666170206144158

8. Ghorbani-Choghamarani A, Darvishnejad Z, Norouzi M (2014) Cu(II)-Schiff base complexfunctionalized magnetic $\mathrm{Fe} 3 \mathrm{O} 4$ nanoparticles: A heterogeneous catalyst for various oxidation reactions. Appl Organomet Chem 29:170-175. https://doi.org/10.1002/aoc.3266

9. Zhang N, Xian G, Li X et al (2018) Iron Based Catalysts Used in Water Treatment Assisted by Ultrasound: A Mini Review. Front Chem 6:1-6. https://doi.org/10.3389/fchem.2018.00012

10. Fan D, Lan Y, Tratnyek PG et al (2017) Sulfidation of Iron-Based Materials: A Review of Processes and Implications for Water Treatment and Remediation. Environ Sci Technol 51:13070-13085. https://doi.org/10.1021/acs.est.7b04177

11. Chu C, Lu C, Yuan J, Xing C (2020) Fate of Fe304@NH2 in soil and their fixation effect to reduce lead translocation in two rice cultivars. Food Sci Nutr 8:3673-3681. https://doi.org/10.1002/fsn3.1651

12. Garner KL (2016) Assessing the Risk of Engineered Nanomaterials in the Environment: Modeling Fate, Exposure, and Bioaccumulation. 118

13. Hartmann NB, Skjolding LM, Hansen SF et al (2014)Environmental fate and behaviour of nanomaterials

14. Kadar E, Rooks P, Lakey C, White DA (2012) The effect of engineered iron nanoparticles on growth and metabolic status of marine microalgae cultures. Sci Total Environ 439:8-17. https://doi.org/10.1016/j.scitotenv.2012.09.010

15. Ali H, Khan E, llahi I (2019) Environmental chemistry and ecotoxicology of hazardous heavy metals: Environmental persistence, toxicity, and bioaccumulation. J Chem 2019:. https://doi.org/10.1155/2019/6730305

16. Yousefi N, Emtyazjoo M, Sepehr MN et al (2020) Green synthesis of Pseudomonas aeruginosa immobilized Fe304-multiwalled carbon nanotubes bio-adsorbent for the removal of 2,4,6trinitrophenol from aqueous solution. Environ Technol Innov 20:101071. https://doi.org/10.1016/j.eti.2020.101071

17. Lei C, Zhang L, Yang K et al (2016) Toxicity of iron-based nanoparticles to green algae: Effects of particle size, crystal phase, oxidation state and environmental aging *. Environ Pollut 4-11. https://doi.org/10.1016/j.envpol.2016.07.030

18. Estevez MS, Malanga G, Puntarulo S (2001) Iron-dependent oxidative stress in Chlorella 6 ulgaris. 161:9-17 
19. Zhu X, Tian S, Cai Z (2012) Toxicity Assessment of Iron Oxide Nanoparticles in Zebrafish (Danio rerio) Early Life Stages. 7:1-6. https://doi.org/10.1371/journal.pone.0046286

20. Behzadi Tayemeh M, Esmailbeigi M, Shirdel I et al (2020) Perturbation of fatty acid composition, pigments, and growth indices of Chlorella vulgaris in response to silver ions and nanoparticles: $A$ new holistic understanding of hidden ecotoxicological aspect of pollutants. Chemosphere 238. https://doi.org/10.1016/j.chemosphere.2019.124576

21. Sayadi MH, Mansouri B, Shahri E et al (2020) Exposure effects of iron oxide nanoparticles and iron salts in black $\mathrm{fi}$ sh (Capoeta fusca): Acute toxicity, bioaccumulation, depuration, and tissue histopathology. Chemosphere 247:125900. https://doi.org/10.1016/j.chemosphere.2020.125900

22. Bavandi R, Emtyazjoo M, Saravi HN et al (2019) Study of capability of nanostructured zero-valent iron and graphene oxide for bioremoval of trinitrophenol from wastewater in a bubble column bioreactor. Electron J Biotechnol 39:8-14. https://doi.org/10.1016/j.ejbt.2019.02.003

23. Krichen E, Rapaport A, Le Floc'h E, Fouilland E (2019) Demonstration of facilitation between microalgae to face environmental stress. Sci Rep 9:1-11. https://doi.org/10.1038/s41598-019$52450-9$

24. Xu H, Lee U, Coleman AM et al (2020) Balancing Water Sustainability and Productivity Objectives in Microalgae Cultivation: Siting Open Ponds by Considering Seasonal Water. https://doi.org/10.1021/acs.est.9b05347. -Stress Impact Using AWARE-US

25. Zhu X, Zhao W, Chen X et al (2020) Growth inhibition of the microalgae Skeletonema costatum under copper nanoparticles with microplastic exposure. Mar Environ Res 158:105005. https://doi.org/10.1016/j.marenvres.2020.105005

26. Xiao S, Liang T, Wong LS (2020) Toxicity of Metals and Metallic. Nanoparticles on Nutritional Properties of Microalgae

27. Wu N, Dong X, Liu Y et al (2017) Using river microalgae as indicators for freshwater biomonitoring: Review of published research and future directions. Ecol Indic 81:124-131. https://doi.org/10.1016/j.ecolind.2017.05.066

28. Andrade LM (2018) Chlorella and Spirulina Microalgae as Sources of Functional Foods, Nutraceuticals, and Food Supplements; an Overview. MOJ Food Process Technol 6. https://doi.org/10.15406/mojfpt.2018.06.00144

29. Nia MV, Emtyazjoo M, Chamani M (2020) Algae usage in producing functional food: A case study on Spirulina platensis for enrichment quail egg. Res Mar Sci 5:2020-2814

30. Bule MH, Ahmed I, Maqbool F et al (2018) Microalgae as a source of high-value bioactive compounds. Front Biosci - Sch 10:197-216. https://doi.org/10.2741/s509

31. Wells ML, Potin P, Craigie JS et al (2017) Algae as nutritional and functional food sources: revisiting our understanding. J Appl Phycol 29:949-982. https://doi.org/10.1007/s10811-016-0974-5

32. Ravi Kiran B, Venkata Mohan S (2021) Photosynthetic transients in Chlorella sorokiniana during phycoremediation of dairy wastewater under distinct light intensities. Bioresour Technol 340:125593. https://doi.org/10.1016/j.biortech.2021.125593 
33. Cho DY, Chung AS, Lee ST, Park SW (1994) Studies on the biosorption of heavy metals onto chlorella vulgaris. J Environ Sci Heal Part A Environ Sci Eng Toxicol 29:389-409.

https://doi.org/10.1080/10934529409376043

34. Goher ME, El-Monem AMA, Abdel-Satar AM et al (2016) Biosorption of some toxic metals from aqueous solution using non-living algal cells of Chlorella vulgaris. J Elem 21:703-714. https://doi.org/10.5601/jelem.2015.20.4.1037

35. Huang Z, Li L, Huang G et al (2009) Growth-inhibitory and metal-binding proteins in Chlorella vulgaris exposed to cadmium or zinc. Aquat Toxicol 91:54-61. https://doi.org/10.1016/j.aquatox.2008.10.003

36. Silkina A, Flynn K, Llewellyn C, Bayliss C (2015) Standard Operating Procedures for Analytical Methods and Data Collection in Support of Pilot-Scale Cultivation of Microalgae. Energ Algae Output WP1A301:395

37. Tsiola A, Pitta P, Giannakourou A et al (2017) Ocean acidification and viral replication cycles: Frequency of lytically infected and lysogenic cells during a mesocosm experiment in the NW Mediterranean Sea. Estuar Coast Shelf Sci 186:139-151. https://doi.org/10.1016/j.ecss.2016.05.003

38. Qian H, Li J, Pan X et al (2011) Combined effect of copper and cadmium on heavy metal ion bioaccumulation and antioxidant enzymes induction in Chlorella vulgaris. Bull Environ Contam Toxicol 87:512-516. https://doi.org/10.1007/s00128-011-0365-1

39. Kuppu R, Manoharan S, Uthandakalaipandian R (2018) A study on the impact of water quality on the murrel fi sh Channa striata and Channa punctata. 11375-11387.

https://doi.org/10.1039/c7ra13583a

40. Alipour H, Banagar GR (2018) Health risk assessment of selected heavy metals in some edible fishes from Gorgan Bay, Iran. Iran J Fish Sci 17:21-34. https://doi.org/10.22092/IJFS.2018.115582

41. Cheng Z, Chen LJ, Li HH et al (2018) Characteristics and health risk assessment of heavy metals exposure via household dust from urban area in Chengdu, China. Sci Total Environ 619-620:621629. https://doi.org/10.1016/j.scitotenv.2017.11.144

42. Cadmus P, Brinkman SF, May MK (2018) Chronic Toxicity of Ferric Iron for North American Aquatic Organisms: Derivation of a Chronic Water Quality Criterion Using Single Species and Mesocosm Data. Arch Environ Contam Toxicol 74:605-615. https://doi.org/10.1007/s00244-018-0505-2

43. Razmovski R, Šćiban M (2008) Iron(III) biosorption by Polyporus squamosus. African J Biotechnol 7:1693-1699. https://doi.org/10.5897/ajb2008.000-5026

44. Feng W, Wang Z, Xu H et al (2020) Species-specific bioaccumulation of trace metals among fish species from Xincun Lagoon, South China Sea. Sci Rep 10:1-11. https://doi.org/10.1038/s41598020-77917-y

45. Torres E, Mera R, Herrero C, Abalde J (2014) Isotherm studies for the determination of Cd (II) ions removal capacity in living biomass of a microalga with high tolerance to cadmium toxicity. Environ Sci Pollut Res 21:12616-12628. https://doi.org/10.1007/s11356-014-3207-y 
46. Sekabira K, Origa HO, Basamba TA et al (2011) Application of algae in biomonitoring and phytoextraction of heavy metals contamination in urban stream water. Int J Environ Sci Technol 8:115-128. https://doi.org/10.1007/BF03326201

47. Marissa C, Naorbe AESJ (2018) Effects of heavy metals on cell density, size, specific growth rate and chlorophyll a of Tetraselmis tetrathele under controlled laboratory. 11:589-597

48. Naorbe MC, Serrano AE (2018) Effects of heavy metals on cell density, size, specific growth rate and chlorophyll a of tetraselmis tetrathele under controlled laboratory conditions. AACL Bioflux 11:589597

49. Bajguz A (2011) Suppression of Chlorella vulgaris growth by cadmium, lead, and copper stress and its restoration by endogenous brassinolide. Arch Environ Contam Toxicol 60:406-416. https://doi.org/10.1007/s00244-010-9551-0

50. Barhoumi L, Dewez D (2013) Toxicity of superparamagnetic iron oxide nanoparticles on green alga Chlorella vulgaris. Biomed Res Int 2013:. https://doi.org/10.1155/2013/647974

51. Metzler DM, Erdem A, Tseng YH, Huang CP (2012) Responses of algal cells to engineered nanoparticles measured as algal cell population, chlorophyll a, and lipid peroxidation: Effect of particle size and type. J Nanotechnol 2012:. https://doi.org/10.1155/2012/237284

52. Sendra M, Blasco J, Araújo CVM (2017) Is the cell wall of marine phytoplankton a protective barrier or a nanoparticle interaction site? Toxicological responses of Chlorella autotrophica and Dunaliella salina to Ag and CeO 2 nanoparticles. Ecol Indic 0-1. https://doi.org/10.1016/j.ecolind.2017.08.050

53. Sendra M, Yeste MP, Gatica JM et al (2017) Direct and indirect effects of silver nanoparticles on freshwater and marine microalgae (Chlamydomonas reinhardtii and Phaeodactylum tricornutum). Chemosphere 179:279-289. https://doi.org/10.1016/j.chemosphere.2017.03.123

54. Ötleş S, Pire R (2001) Fatty acid composition of Chlorella and Spirulina microalgae species. J AOAC Int 84:1708-1714. https://doi.org/10.1093/jaoac/84.6.1708

55. Ferrazzano GF, Papa C, Pollio A et al (2020) Cyanobacteria and microalgae as sources of functional foods to improve human general and oral health. Molecules 25:1-17. https://doi.org/10.3390/molecules 25215164

56. Katiyar R, Arora A (2020) Health promoting functional lipids from microalgae pool: A review. Algal Res 46:101800. https://doi.org/10.1016/j.algal.2020.101800

57. Fields FJ, Lejzerowicz F, Schroeder D et al (2020) Effects of the microalgae Chlamydomonas on gastrointestinal health. J Funct Foods 65:103738. https://doi.org/10.1016/j.jff.2019.103738

\section{Figures}



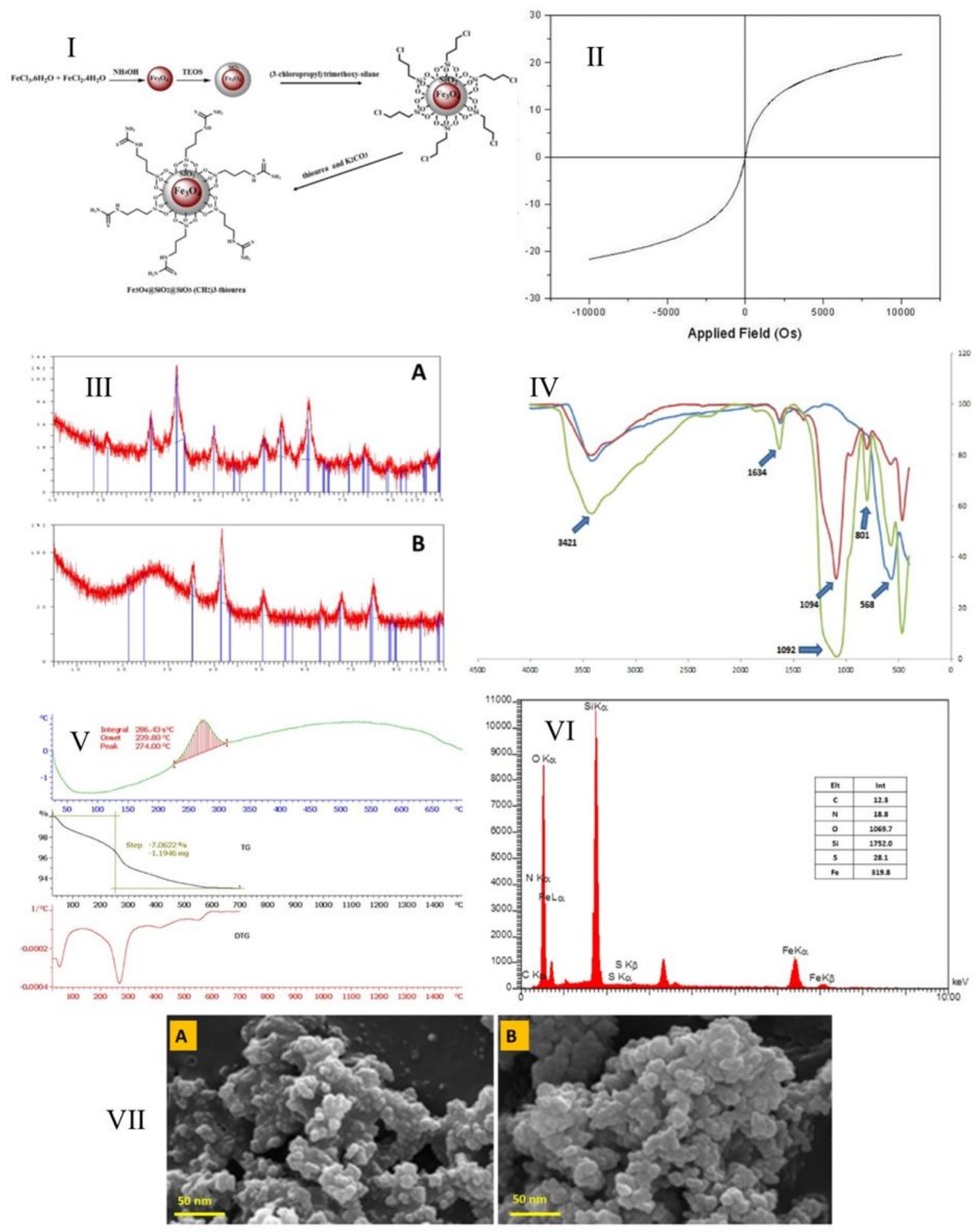

\section{Figure 1}

Schematic of synthesized catalyst Fe304@SiO2@SiO3-(CH2)3-thiourea (I), magnetization curve of Fe304@SiO2@SiO3-(CH2)3-thiourea (II),XRD pattern of Fe3O4 (III-A) and Fe3O4@SiO2@SiO3-(CH2)3thiourea (III-B), FT-IR spectra of Fe304 (IV-blue curve), Fe304@SiO2 (IV-red curve) and Fe304@SiO2@SiO3-(CH2)3-thiourea (IV-green curve), thermogravimetric analysis of Fe3O4@SiO2@SiO3- 
(CH2)3-thiourea (V), EDX spectrum of Fe304@SiO2@SiO3-(CH2)3-thiourea (VI), SEM Analysis of the Fe304@SiO2@SiO3-(CH2)3-thiourea (VII-A), Fe3O4@SiO2@SiO3-(CH2)3-thiourea after reaction (VII-B).

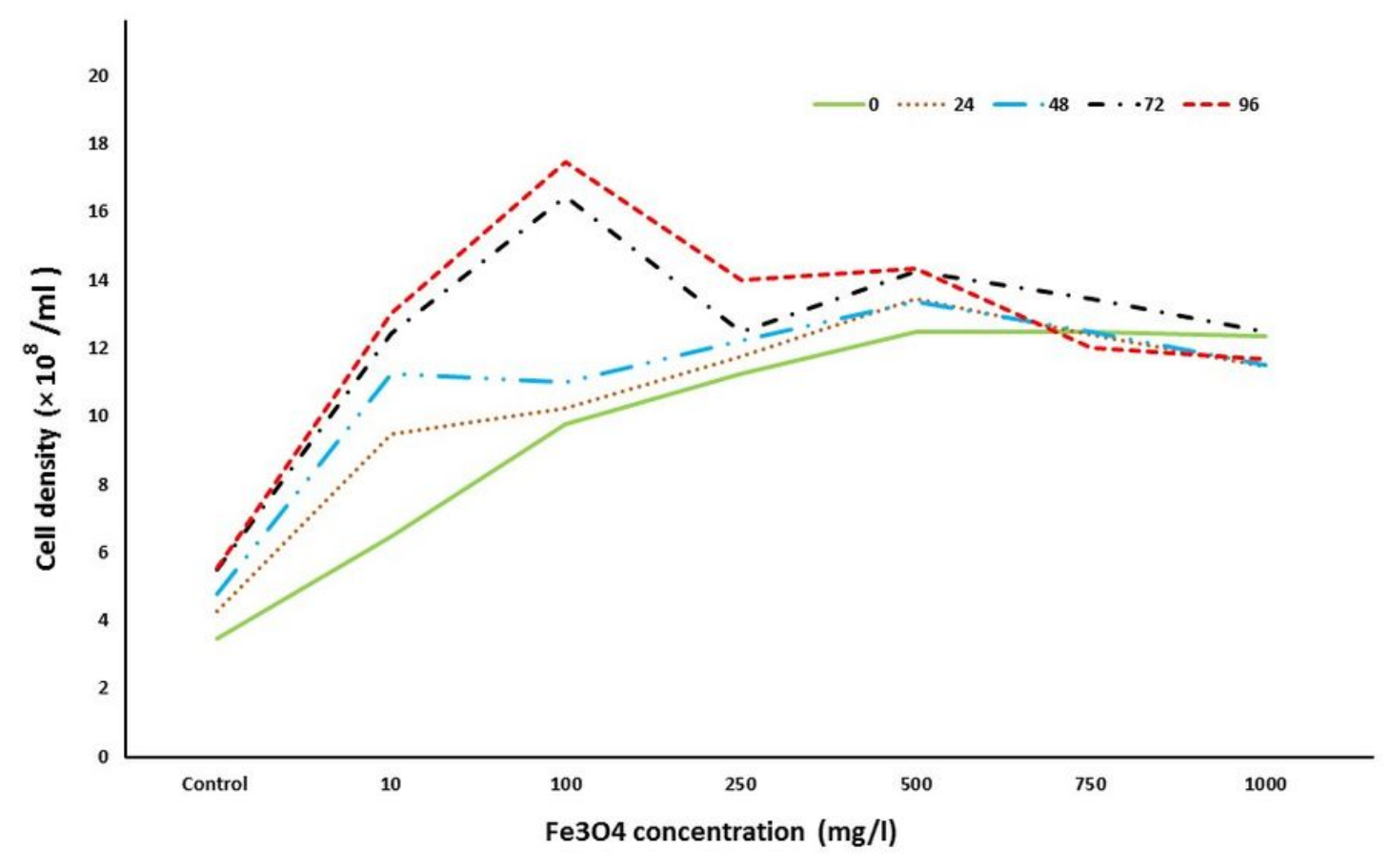

Figure 2

Cell density of C. vulgaris exposed to different concentrations of Fe304 in a 96-h period. 


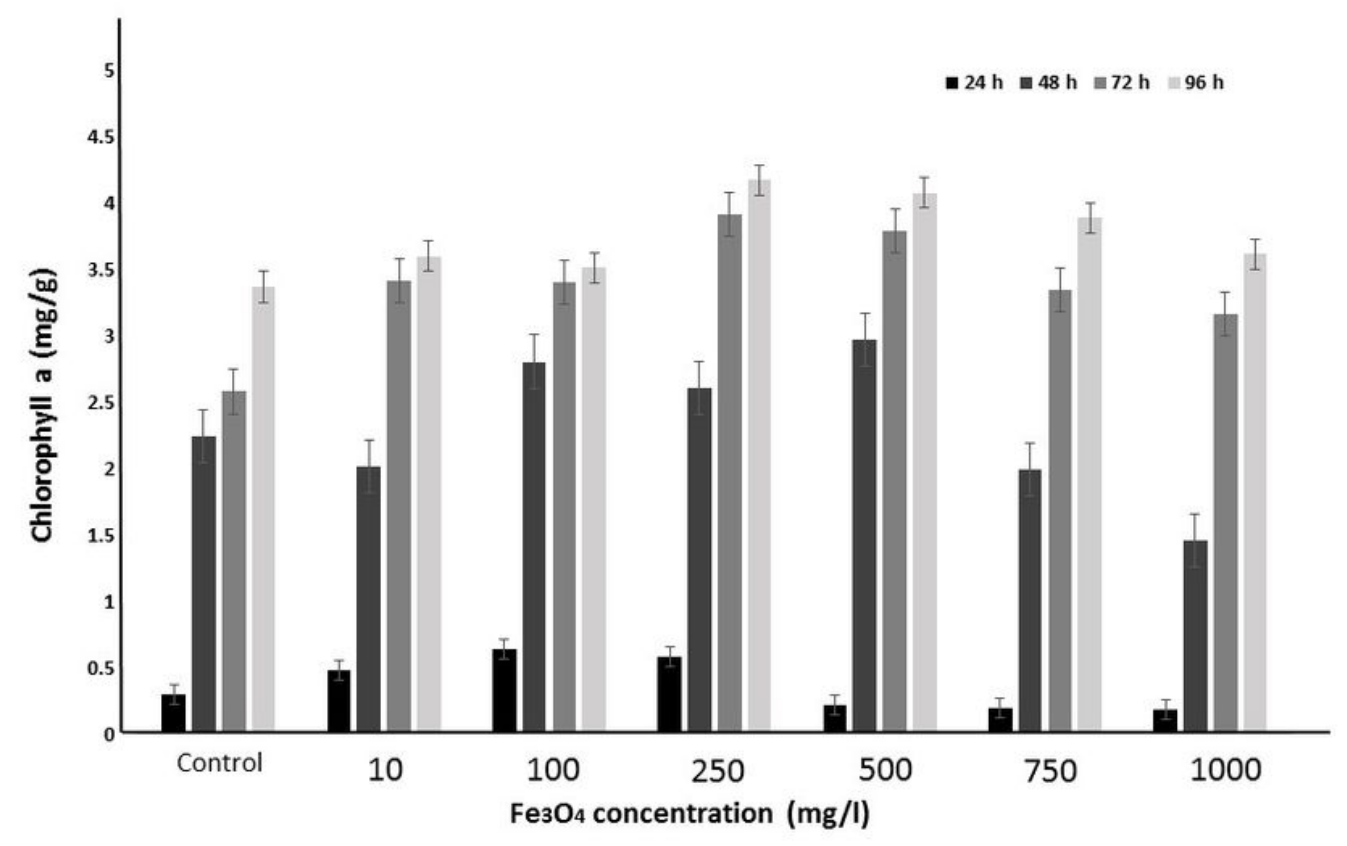

Figure 3

Chlorophyll a content of C. vulgaris exposed to different concentrations of Fe304 in a 96-h period.

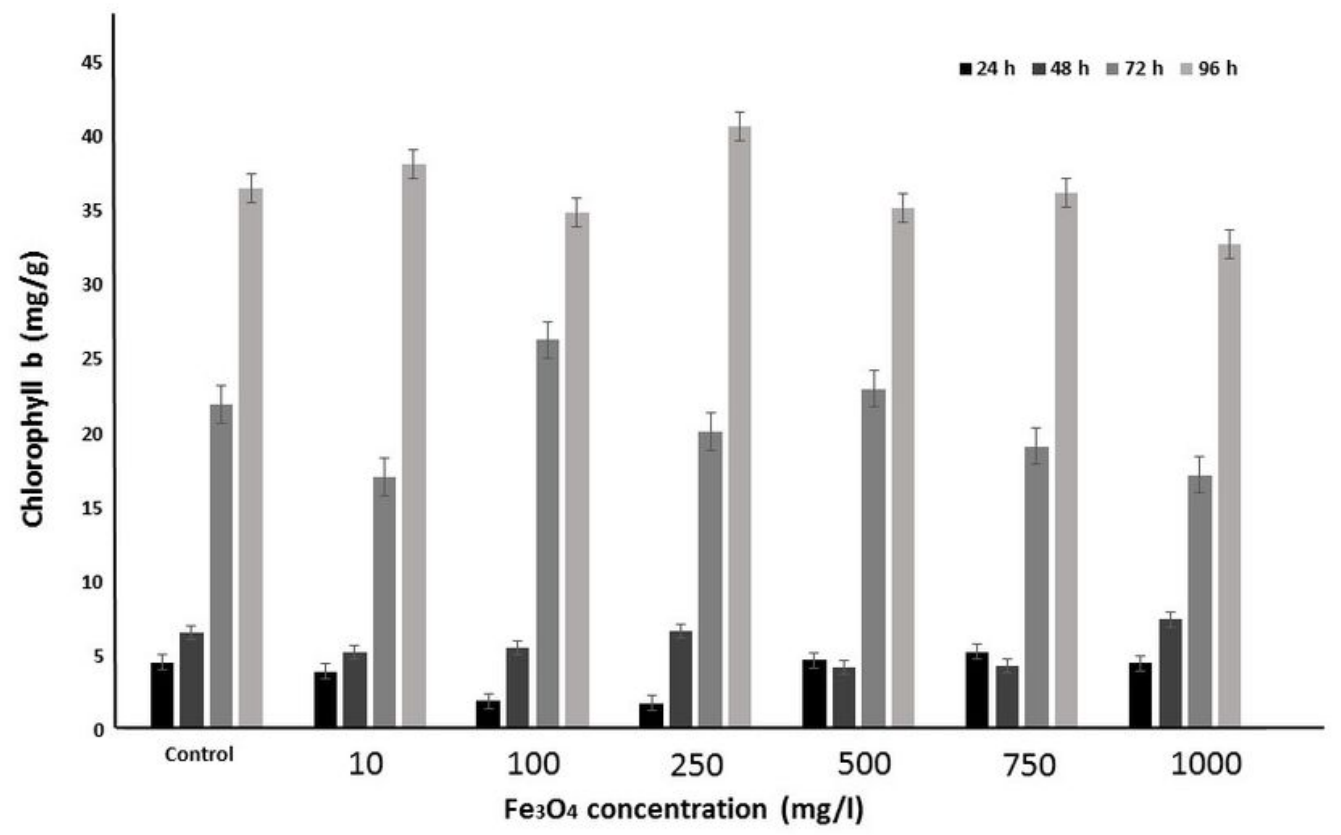


Figure 4

Chlorophyll b content of C. vulgaris exposed to different concentrations of Fe304 in a 96-h period.

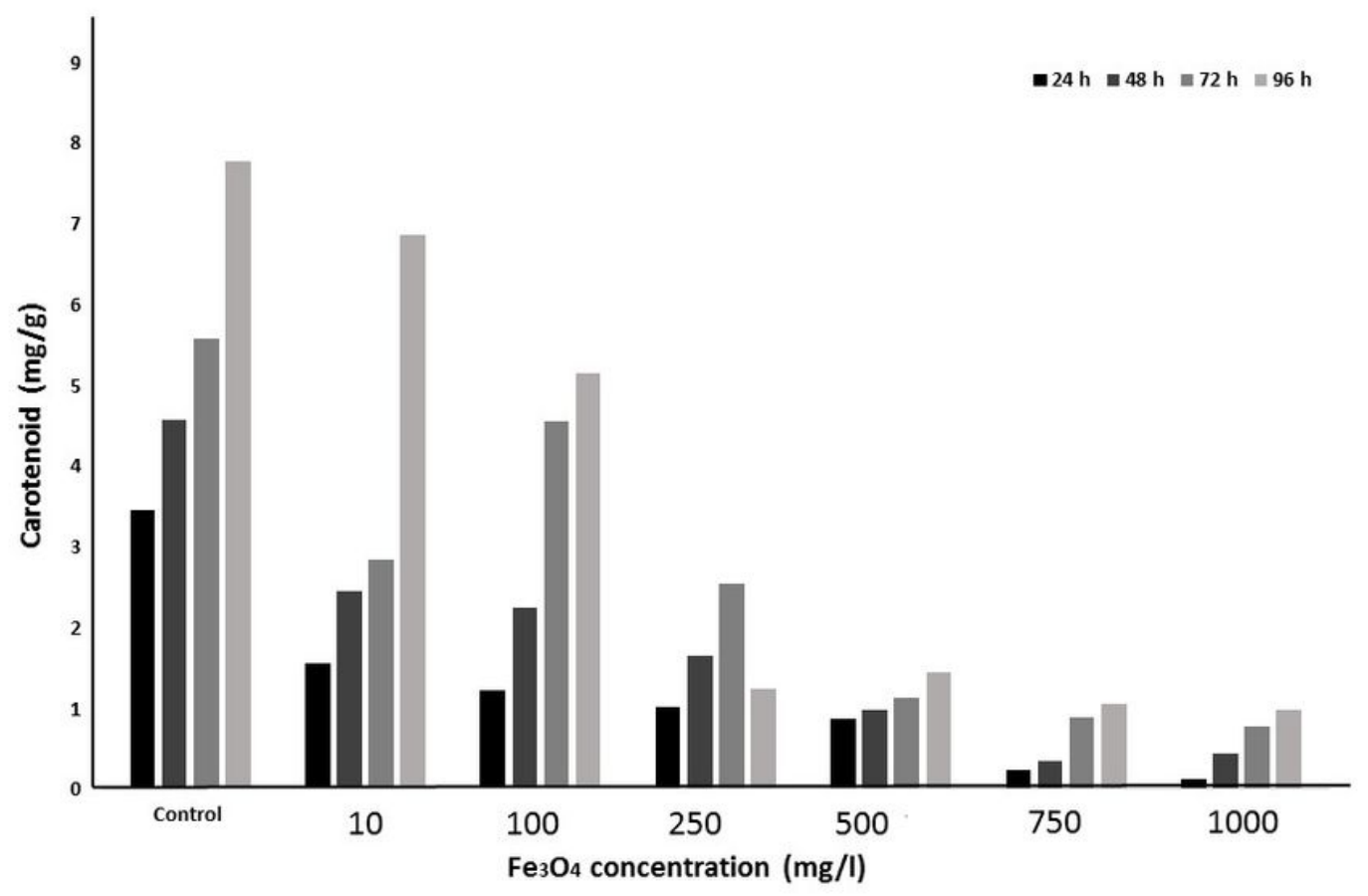

Figure 5

Carotenoid content of C. vulgaris exposed to different concentrations of Fe304 NPs in a 96-h period. 


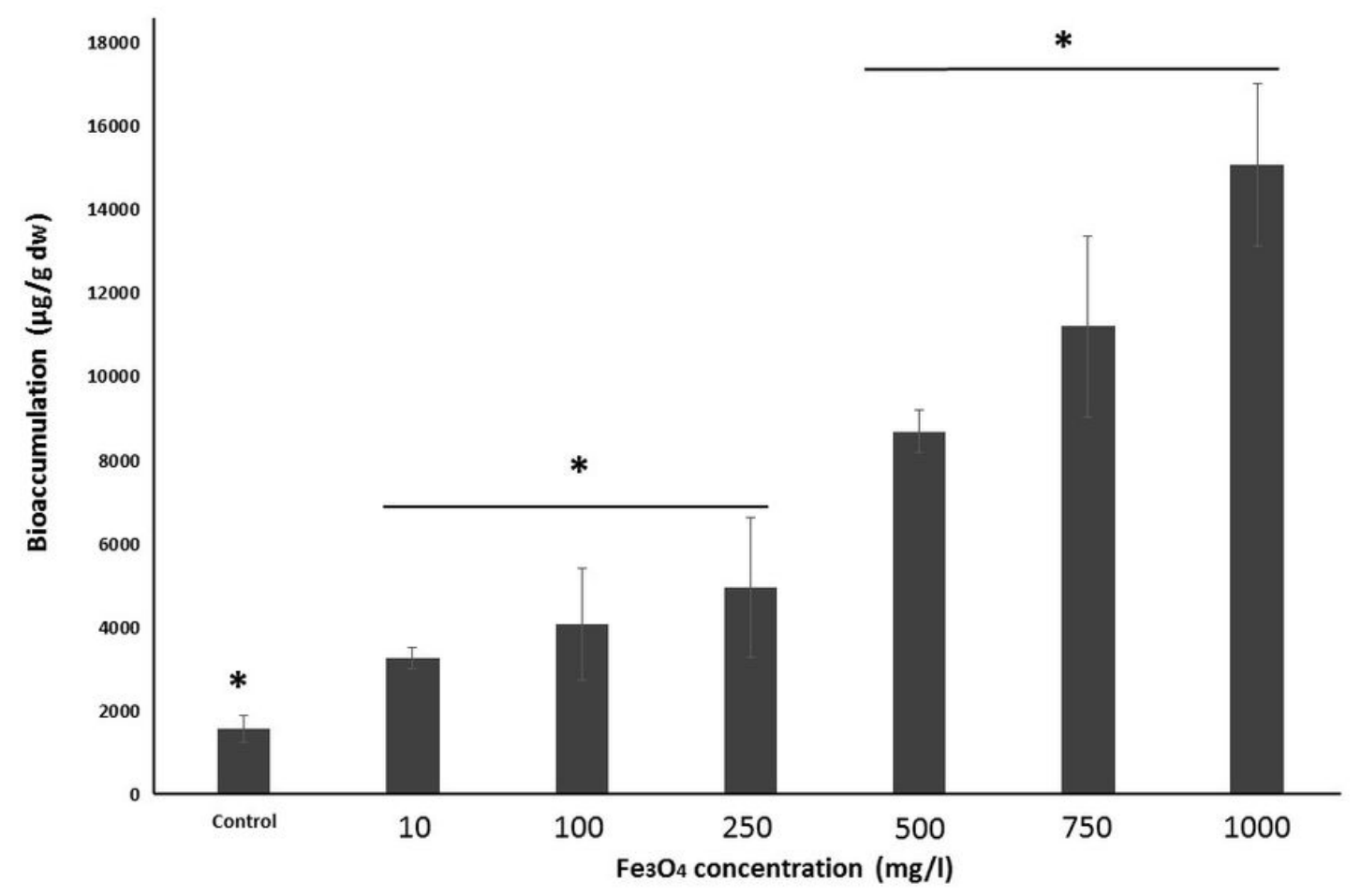

Figure 6

Bioaccumulation of $\mathrm{Fe} 3 \mathrm{O} 4$ in C. vulgaris during a 96-h exposure period (* indicates significant differences).

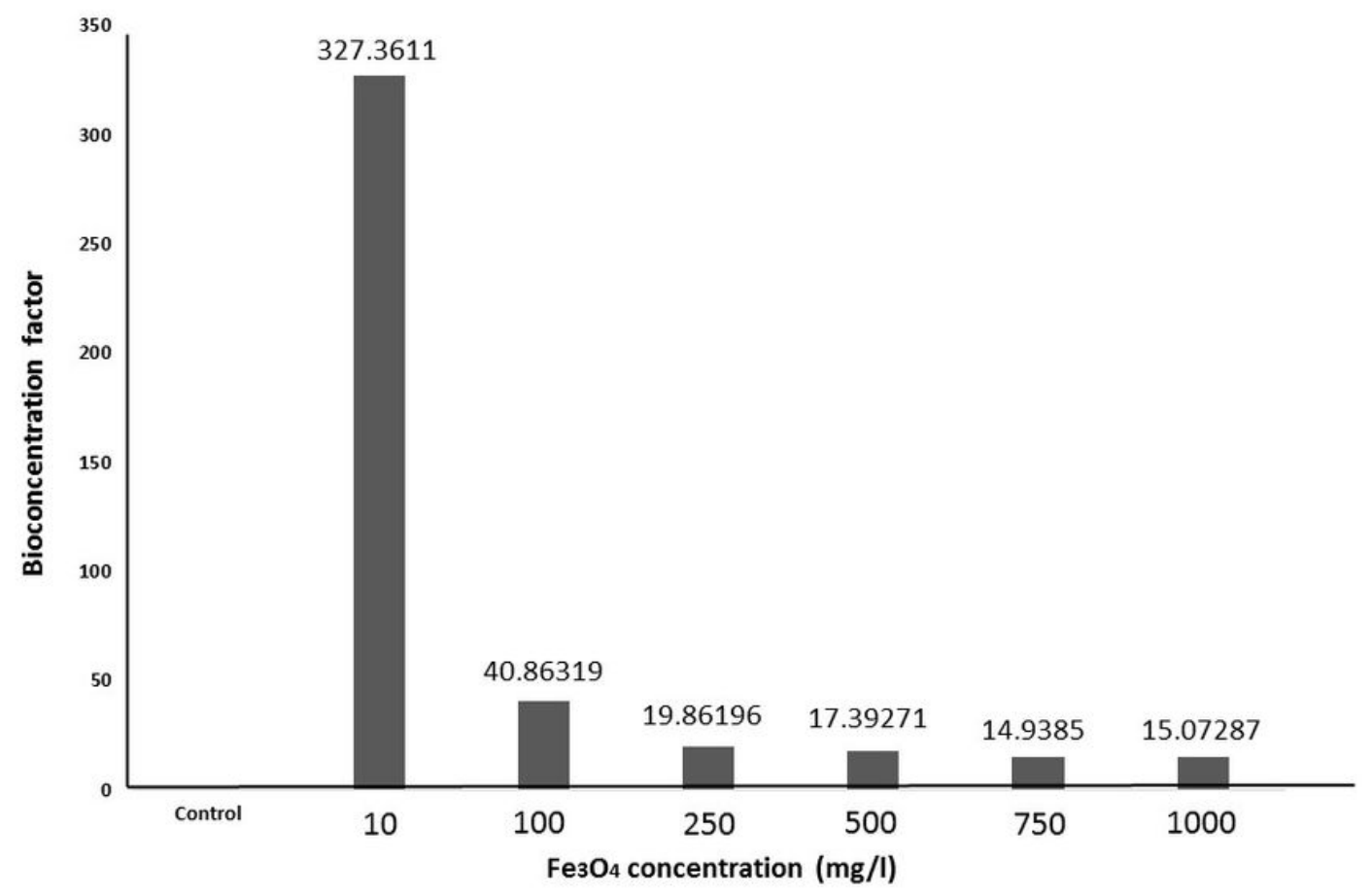


Figure 7

Bioconcentration factor of $\mathrm{Fe} 304$ in C. vulgaris during a 96-h exposure period. 